\title{
Development of a biomass energy dryer assisted with solar energy for farmers in off-grid communities
}

\author{
Wannarat Chuatrakool $^{1 *}$, Siva Achariyaviriya ${ }^{1 \dagger}$, Aree Achariyaviriya ${ }^{1}$, and James C. Moran ${ }^{1}$ \\ ${ }^{1}$ Chiang Mai University, Department of Mechanical Engineering, 50200, Chiang Mai, Thailand
}

\begin{abstract}
The objectives of this research are to design and construct a biomass energy dryer assisted with solar energy for farmers in off-grid communities and to evaluate the performance of the dryer. The dryer consists of a boiler, drying chamber and solar panels. A compressed sponge was used as a drying product. The air temperature distribution and product moisture uniformity inside the drying chamber were measured. The apparatus was tested in three energy modes, solar energy mode, biomass energy mode and biomass/solar energy assisted mode. Drying using biomass/solar energy assisted mode gave a better drying performance compared to the other modes due to the uniform moisture content and air temperature. The average temperature difference between the top and bottom tray was less than $3^{\circ} \mathrm{C}$. The average moisture content between the top and bottom tray was very close, less than $0.8 \% \mathrm{db}$. In addition, this drying mode can reduce product contamination from smoke ash and combustion.
\end{abstract}

\section{Introduction}

Thailand is an agricultural country with most of the population involved in farming. According to Belessiotis and Delyannis [1] who reported that many crops are lost after harvesting because they lack safe product storage resulting in spoilage and oversupply. If the crops are dried this could extend product life and make transportation convenient. Drying also helps to reduce microbial contamination [2]. Accordingly, the goal of this project is to design and develop a hybrid dryer for farmers in off-grid communities. Thermal energy from solar energy can be used, and in times when the solar radiation is unavailable, such as nighttime other heat sources can be used. Solar helps to increase drying efficiency and reduce the drying time. Sontakke et al. [3] and Borompichaichartkul [4] have shown that auxiliary heat sources used include solar collector, heat pump, microwave, infrared rays, and biomass energy. Chunsri [5] reported a study on the performance of a solar biomass hybrid dryer for drying $2 \mathrm{~kg}$ of chili, which took $15 \mathrm{~h}$. They found that the specific energy consumption was $1.25 \mathrm{MJ} / \mathrm{kg}_{\text {water }}$. Aritesty and Wulandani [6] reported that the performance of a greenhouse

\footnotetext{
* Corresponding author: misswannarat@gmail.com

$\dagger$ Corresponding author: siva@dome.eng.cmu.ac.th
} 
solar dryer assisted with biomass for drying of $60 \mathrm{~kg}$ wild ginger was dried within $30 \mathrm{~h}$. They found that the specific energy consumption was $29.2 \mathrm{MJ} / \mathrm{kg}_{\text {water }}$ and an overall dryer efficiency of $8.2 \%$. From the research mentioned, many of them use electric power as an energy source. Therefore, research to develop a dryer for use in areas that are not connected to the electric grid is ongoing. Achariyaviriya et al. [7] reported that the development of a biomass dryer for drying $15 \mathrm{~kg}$ of honey bananas was dried within $34 \mathrm{~h}$. They found that the specific energy consumption was $71.67 \mathrm{MJ} / \mathrm{kg}_{\text {water. }}$. Essalhi et al. [8] reported that a solar aircollector for indirect solar drying of $1 \mathrm{~kg}$ pear was dried within $24 \mathrm{~h}$. They found that the overall dryer efficiency was $11.11 \%$. From the research dryers mentioned, the use of natural convection caused the product to become unevenly dried due to the temperature distributed inside the drying chamber. This research developed forced convection dryer using electricity from solar panels. The objectives of this research are to design and construct a biomass dryer assisted with solar energy for farmers in off-grid communities and to carry out an evaluation of the dryer performance.

\section{Materials and methods}

The experiments were conducted from October to November 2019 at Mae Rim District, Chiang Mai Province, Thailand. The dryer consists of a drying chamber, a boiler and solar panels.

\subsection{Drying chamber}

The drying chamber was built in a parabolic shape, covered by polycarbonate sheets to receive solar radiation directly. In the drying chamber, there are 2 stainless-steel trolleys, 28 trays, 3 fans and a heat exchanger.

\subsection{Boiler set}

The boiler set consists of two parts; the lower part is a biomass stove with a blower. The upper part is a water pot made from stainless steel and insulated on the outside. There are water pumps for pumping water from the pot to a heat exchanger inside the drying chamber.

\subsection{Solar cell panels}

Polycrystalline solar panels were connected in parallel with two batteries. The list of specifications and instrumentations in the experiment are shown in Table 1.

The dryer is operated using biomass energy for boiling water supplied to the heat exchanger. Electricity from solar panels is used to operate a blower, water pumps, fans and the control system, see Figure 1.

\subsection{Drying product}

The drying product was a compressed sponge which was prepared by cutting into squares a moistened compressed sponge (width $\times$ length $\times$ height) $10 \times 10 \times 1 \mathrm{~cm}^{3}$. The initial moisture content was about $320 \% \mathrm{db}$. 
Table 1. Specifications and instrumentations used in the experiment.

\begin{tabular}{ll}
\hline \multicolumn{1}{c}{ Parameters } & \multicolumn{1}{c}{ Details } \\
\hline Drying chamber & \\
Drying chamber area (width x length x height) & $1.5 \times 2 \times 1.5 \mathrm{~m}^{3}$ \\
Trolley (width x length x height, quantity) & $45 \times 60 \times 115 \mathrm{~cm}^{3}, 2$ \\
Tray (width x length, quantity), total trays & $40 \times 60 \mathrm{~cm}^{2}, 28$ \\
Drying capacity & $80 \mathrm{~kg}$ \\
\hline Boiler & \\
Biomass stove size (diameter, height) & $45 \mathrm{~cm}, 60 \mathrm{~cm}$ \\
Water pot size (diameter, height) and pot capacity & $45 \mathrm{~cm}, 40 \mathrm{~cm} 0.064 \mathrm{~m}^{3}$ \\
Blower (voltage, current) & $12 \mathrm{~V}, 1.2 \mathrm{~A}$ \\
Water pump (voltage, current) & $12 \mathrm{~V}, 2 \mathrm{~A}$ \\
\hline Solar cell panels & \\
Model, total panels & $\mathrm{LTS} 160-36,2$ \\
Dimension & $68 \times 148 \times 3.5 \mathrm{~cm}^{3}$ \\
Maximum power/Pmax & $160 \mathrm{~W}$ \\
\hline Instrumentation & \\
Pyranometer Apogee SP-215-5s (accuracy, radiation range) & $\pm 5 \%, 0-2,000 \mathrm{~W} / \mathrm{m}^{2}$ \\
Thermocouple Type-K (accuracy, temperature range) & $\pm 1.5 \%,-40-1,000^{\circ} \mathrm{C}$ \\
Analytical Balance Satorius EA35ED (accuracy) & $0.001 \mathrm{~g}$ \\
Infrared Thermometer (accuracy, radiation range) & $\pm 1 \%,-30-900^{\circ} \mathrm{C}$ \\
\hline
\end{tabular}

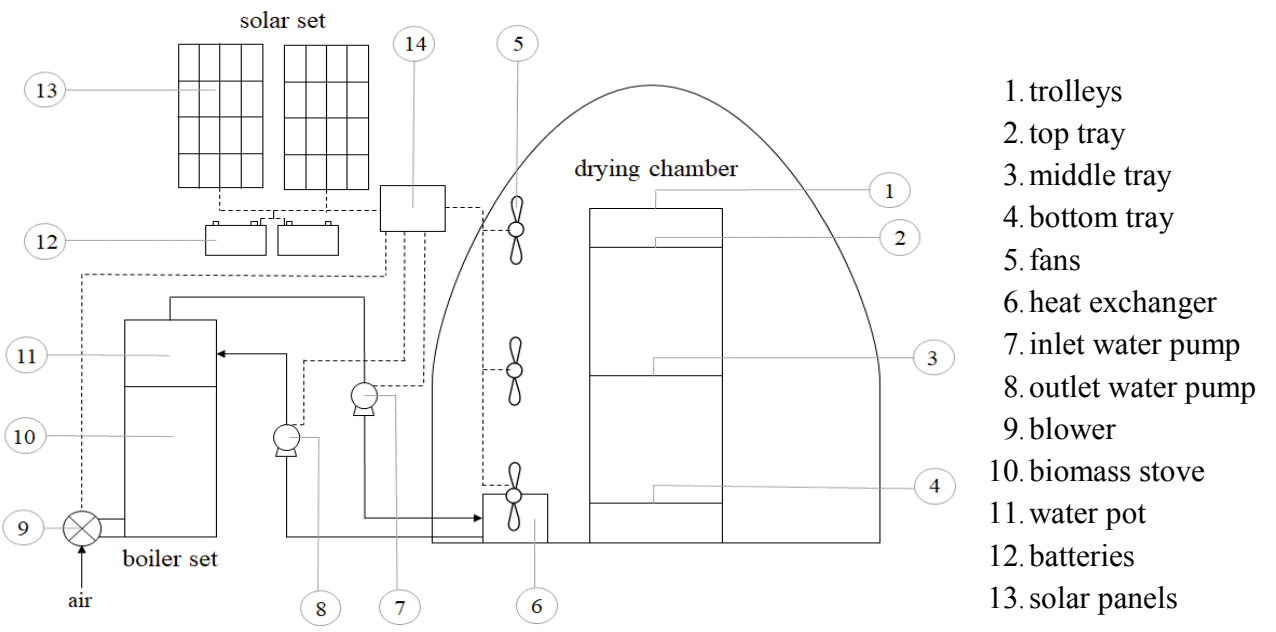

Fig. 1. Schematic diagram of the biomass energy dryer assisted with solar energy.

\subsection{Experimental method}

Drying the moistened compressed sponge was carried out using 14 trays. Experimental data was gathered from 3 trays including the top, middle and bottom tray. Weights of the product were measured every $15 \mathrm{~min}$ by digital weight balance. The solar intensity is also measured every $15 \mathrm{~min}$ by a pyranometer. The air temperature was measured every $30 \mathrm{~min}$ by thermocouples. 9 temperature measurement positions were divided into the upper positions (T4 and top tray), middle positions (T1, T2, T5, T6 and middle tray) and lower positions (T3 and bottom tray) in Figure 2. 


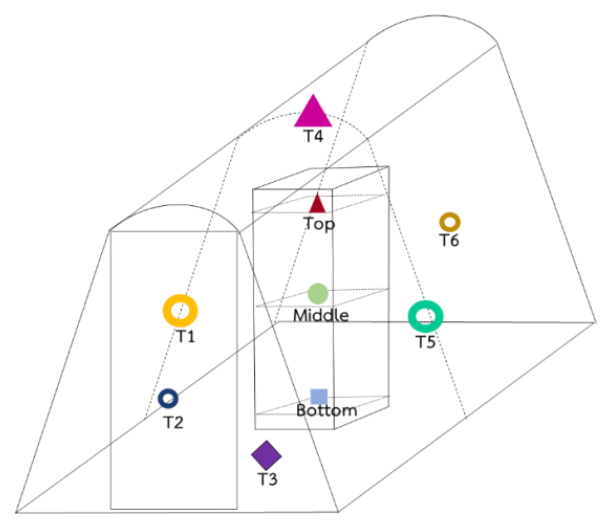

Fig. 2. Positions of the measurement temperature inside the drying chamber

The experiment was divided into 3 energy modes as follows: 1) Drying using solar energy mode, running the dryer in the daytime from 10.30 AM to 2.30 PM. 2) Drying using biomass energy mode, running the dryer in the nighttime from 18.15 PM to 10.45 PM. 3) Drying using biomass/solar energy assisted mode, running the dryer in the daytime using both modes of energy at the same time from 12.20 PM to 3.20 PM.

\subsection{Experimental data analysis}

The specific drying rate $(S D R)$ is the ratio of the drying rate in $\mathrm{kg}_{\text {water }} / \mathrm{h}$ and the mass of dry bone product in $\mathrm{kg}$. It is calculated from

$$
S D R=\frac{M_{f}-M_{i}}{t}
$$

Where " $M_{f}$ " is the final moisture content in decimal dry basis, " $M_{i}$ " is the initial moisture content in decimal dry basis and " $t$ " is drying time in h.

The specific energy consumption (SEC) is the ratio of thermal energy used for drying and the mass of water evaporated from product. It is calculated from

$$
S E C=\frac{E}{m_{b}\left(M_{f}-M_{i}\right)}
$$

Where " $E$ " is thermal energy in MJ. and " $m_{b}$ " is the mass of dry product in kg.

\section{Results and discussion}

\subsection{The air temperature distribution inside the drying chamber}

The air temperature distribution inside the drying chamber was measured at 6 positions, the left side (T1), front side (T2), bottom side (T3), top side (T4), right side (T5) and backside ( T6). The drying experiments were carried out in 3 different modes, solar energy mode, biomass energy mode, and biomass/solar energy assisted mode. Each is outlined as follows: 


\subsubsection{Solar energy mode}

The drying experiment was conducted during the daytime. The average of solar intensity was $555 \mathrm{~W} / \mathrm{m}^{2}$. The average temperature in the drying chamber varied between $51{ }^{\circ} \mathrm{C}$ to $57^{\circ} \mathrm{C}$. In the drying chamber, the maximum and minimum temperature difference at any time of running the dryer was $35^{\circ} \mathrm{C}$ and $11.50^{\circ} \mathrm{C}$ respectively. Before running the dryer, the temperature in the drying chamber had a relatively high temperature difference because of no force convective heat transfer inside the drying chamber. After the fans were turned on to circulate hot air, the temperature differences decreased. The maximum temperature occurred at the top side (T4) due to receiving heat directly from solar radiation. The minimum temperature occurred at the backside (T6) due to the lowest air circulation, see Figure 3.

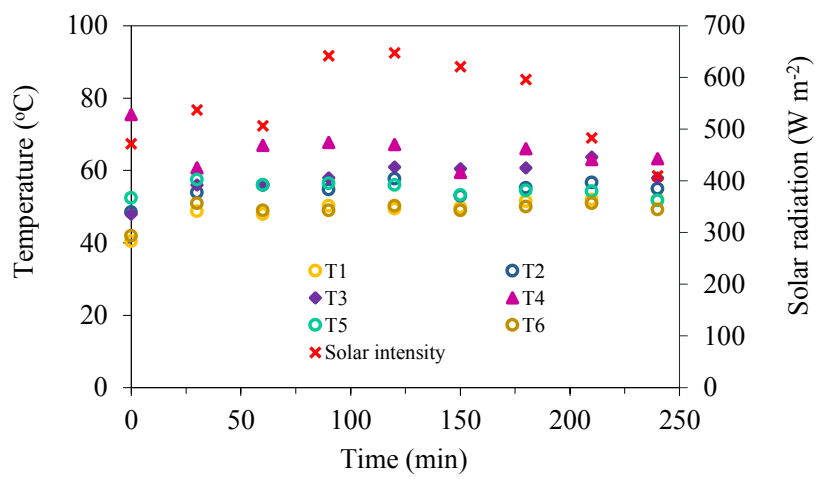

Fig. 3. Comparison temperature of various positions using solar energy mode.

\subsubsection{Biomass energy mode}

During the nighttime, a drying experiment was conducted using $12 \mathrm{~kg}$ biomass charcoal. The average temperature varied between $47^{\circ} \mathrm{C}$ to $54^{\circ} \mathrm{C}$. The maximum and minimum temperature difference at any time of running the dryer was $20^{\circ} \mathrm{C}$ and $16^{\circ} \mathrm{C}$, respectively. During the nighttime, the temperature in the drying chamber had a relatively low temperature difference inside the drying chamber. After, the dryer operation it was found that the temperature differences within the drying chamber were very close. The maximum temperature occurs at the right side (T5) due to receiving heat directly from the heat exchanger. The minimum temperature occurs at the backside (T6) due to the low air circulation, see Figure 4.

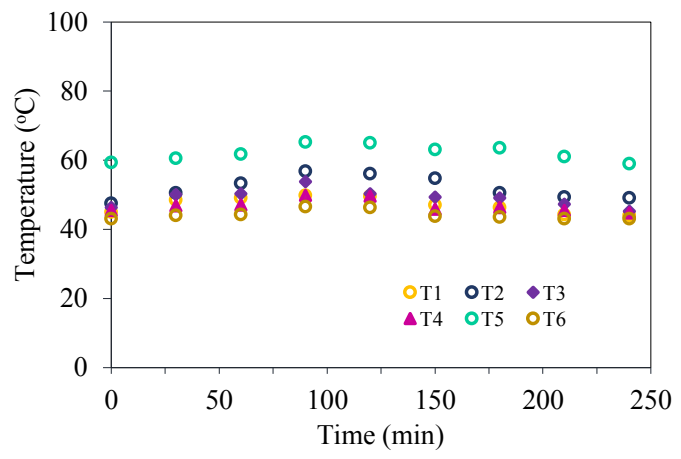

Fig. 4. Temperature at various positions in biomass energy mode. 


\subsubsection{Biomass/Solar energy assisted mode}

The experiment was conducted during the daytime. The average of solar intensity was 436 $\mathrm{W} / \mathrm{m}^{2}$ and $6.5 \mathrm{~kg}$ biomass charcoal was used. The average temperature varied between $50^{\circ} \mathrm{C}$ to $61^{\circ} \mathrm{C}$. The maximum and minimum temperature difference at any time of running the dryer was $17.5^{\circ} \mathrm{C}$ and $11.5^{\circ} \mathrm{C}$, respectively. The maximum temperature occurred at the top side (T4) and the minimum temperature occurred at the backside (T6), see Figure 5.

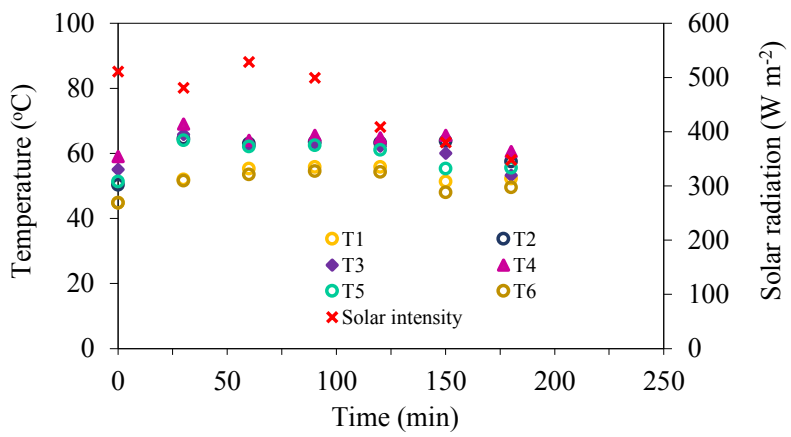

Fig. 5. Temperature at various positions using biomass/solar energy assisted mode.

The air temperature distribution inside the drying chamber using thermal energy in three modes found that the drying using biomass/solar energy assisted mode has the best temperature distribution due to the circulating effect of the fans on the hot air from the heat exchanger.

\subsection{Moisture uniformity}

The moisture uniformity and air temperature distribution in the drying chamber were measured at 3 positions, the top, middle and bottom tray. The experiments were also carried out in 3 modes, namely solar energy mode, biomass energy mode and biomass/solar energy assisted mode.

\subsubsection{Solar energy mode}

It was found that the average temperature of the top, middle, and bottom tray was $56^{\circ} \mathrm{C}, 55^{\circ} \mathrm{C}$, and $54^{\circ} \mathrm{C}$, respectively. The moisture content of the product was uniform before drying started. The moisture difference (top and bottom tray) increased with drying time until 120 min, then it decreased. The moisture content of the top tray was lower than the middle and bottom tray. The maximum moisture difference was $121 \% \mathrm{db}$. At the end of drying, the moisture difference was $2 \% \mathrm{db}$, see Figure 6.

\subsubsection{Biomass energy mode}

The average temperature of top, middle, and bottom tray was $57^{\circ} \mathrm{C}, 53^{\circ} \mathrm{C}$, and $51^{\circ} \mathrm{C}$, respectively. The initial moisture content of the product was uniform. The moisture difference (top and bottom tray) increased with drying time in the first half period and then decreased. The maximum moisture difference was $86 \% \mathrm{db}$ and it was $0.8 \% \mathrm{db}$ at the end of drying, see Figure 7. 


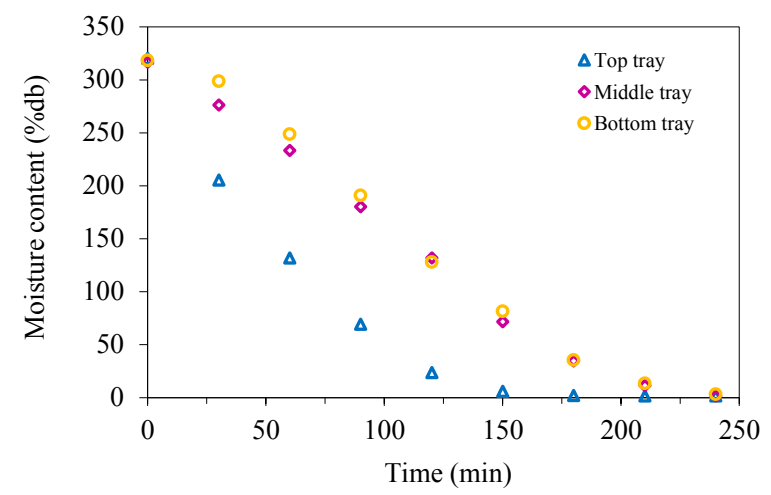

Fig. 6. Moisture comparison of the top, middle and bottom tray in solar energy mode

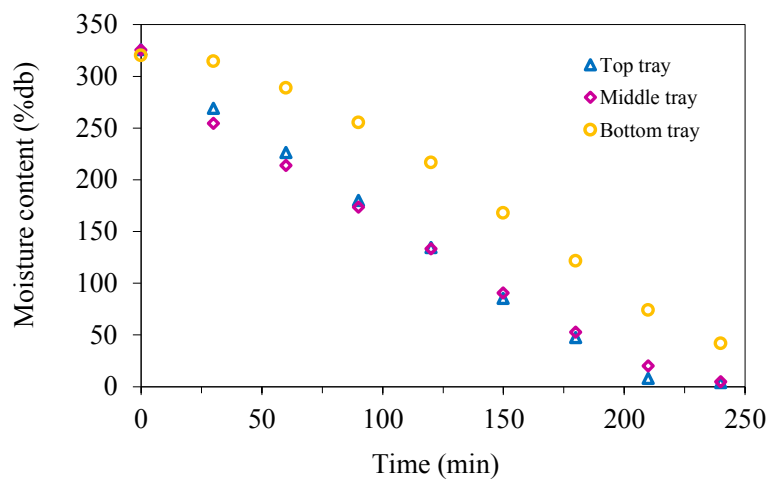

Fig. 7. Moisture comparison of the top, middle and bottom tray in biomass energy mode.

\subsubsection{Biomass/solar energy assisted mode}

The average temperature of the top, middle and bottom tray was $58^{\circ} \mathrm{C}, 59^{\circ} \mathrm{C}$, and $61^{\circ} \mathrm{C}$, respectively. The maximum moisture difference, at $45 \mathrm{~min}$, was $38 \% \mathrm{db}$. At the end of drying, the moisture difference (top and bottom tray) was $3 \% \mathrm{db}$. The moisture content in each tray was uniform, see Figure 8.

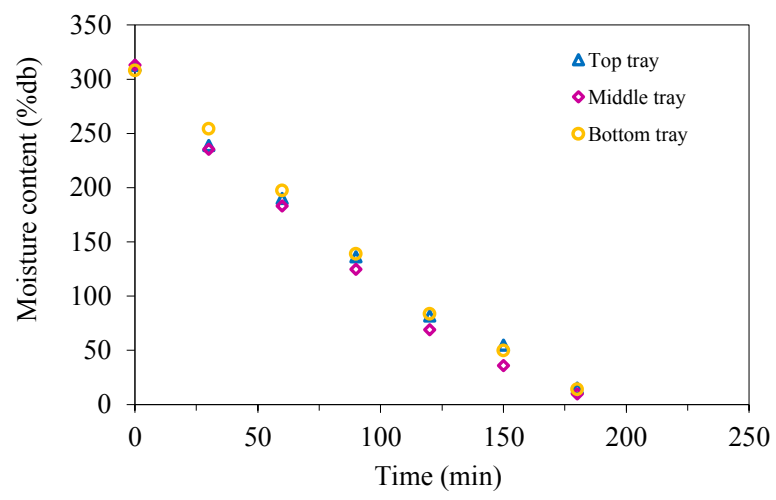

Fig. 8. Moisture comparison of the top, middle and bottom tray in biomass/solar energy assisted mode. 
The best result was when drying was carried out in biomass/solar energy assisted mode. The moisture difference in this mode is the least. The moisture content of all trays decreased at nearly the same rate. Additionally, the moisture difference using this dryer is less than the moisture difference using the dryer developed by Achariyaviriya et al. [7] because this dryer has the fans for air recirculation. Therefore, the moisture content is more uniform.

\subsection{Specific drying rate and specific energy consumption}

The specific drying rate using solar energy mode, biomass energy mode and biomass/solar energy assisted mode was $0.79,0.70$ and $0.98 \mathrm{~kg}_{\text {water }} / \mathrm{kg}_{\text {product }} / \mathrm{h}$ respectively, and the specific energy consumption was $17.43,91.19$ and $60.73 \mathrm{MJ} / \mathrm{kg}_{\text {water }}$, respectively.

\section{Conclusions}

Dryer performance using three thermal energy modes were studied for evaluating the air and moisture distribution. It was found that using biomass/solar energy assisted mode gave a better drying performance compared to the other modes. The average air temperature varied between $50^{\circ} \mathrm{C}$ to $61^{\circ} \mathrm{C}$. The average temperature difference between the top and bottom tray was less than $3^{\circ} \mathrm{C}$. The moisture content in all trays dried at nearly the same rate and in a uniform manner. The moisture difference between the top and bottom tray was less than $0.8 \%$ $\mathrm{db}$. This dryer is suitable for use in off-grid communities. Now, it is installed at Ler-tor-gold Community Enterprise, Tak Province, Thailand.

The authors would like to thank NHK-SPRING (Thailand) Co., Ltd. for research funding and cultivator in Mae Rim District, Chiang Mai Province, Thailand for facilitating the compilation of research results.

\section{References}

1. V. Belessiotis, E. Delyannis, Eng. 85 (2011)

2. SME Knowledge center, Available at: https://www.sme.go.th/upload/mod_download/ download-20181005083327.pdf. (2018) Accessed on 15 December 2019.

3. M.S. Sontakke, S.P. Salve, Sol. Eng. 4 (2015)

4. C. Borompichaichartkul, KMUTT. J. 35 (2012)

5. S.N. Chunsri, SWU. J. 12 (2017)

6. E. Aritesty, D. Wulandani, Eng. Proc. 47 (2014)

7. S. Achariyaviriya, P. Chunkeaw, A. Achariyaviriya, Development of honey bananas dryer using biomass energy, in Proceedings of the Fifteenth Conference on Energy Network of Thailand, 591-596. Suranaree University of Technology. 21-24 May 2019, Nakhon Ratchasima, Thailand. (2019)

8. H. Essalhi, R. Tadili, M.N. Bargach, Eng. Proc. 141 (2017) 